\title{
Effect of the anode composition on the performance of reversible
} chlor-alkali electro-absorption cells

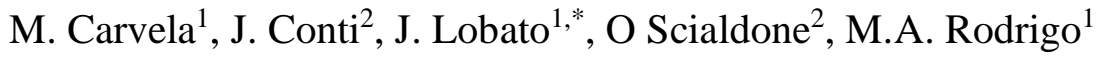 \\ ${ }^{1}$ University of Castilla-La Mancha, Faculty of Chemical Sciences \& Technologies, \\ Chemical Engineering Department, Av. Camilo José Cela, 12. 13071 Ciudad Real, Spain. \\ ${ }^{2}$ Università degli Studi di Palermo, Dipartimento di Ingegneria, Viale delle Scienze, \\ Palermo, Italy.
}

\begin{abstract}
In this work, the performances of a reversible electrochemical cell for the storage of energy using the chloralkaline process was investigated. The cell operates at room temperature with liquid electrolytes in both compartments. In the electrolyzer mode, the cell transforms a sodium chloride solution into hydrogen and chlorine, which is then disproportionated to form hypochlorous acid and hypochlorite. In fuel cell operation mode, the cell becomes an electro-absorber to oxidize hydrogen at the anode while reducing hypochlorous acid at the cathode. Because of the low solubility of hydrogen, a special mechanical device is used to produce hydrogen microbubbles in the anodic compartment. The influence of the ratio $\mathrm{Ru} / \mathrm{Pt}$ in the electrode devoted to the electrochemistry of chlorine species is also evaluated. It was found that a molar ratio $\mathrm{Ru}: \mathrm{Pt}$ in the range 3-4 was good enough to obtain a good performance in both operation modes (electrolyzer and fuel cell). In the electrode in charge of the hydrogen electrochemistry a platinum coating on $\mathrm{Ti}$ was used and it demonstrates robustness enough to obtain good operation results. Maximum efficiency in the electrolysis mode
\end{abstract}


was $8.0 \mathrm{mmol} \mathrm{H}_{2} / \mathrm{Wh}$ while in the fuel cell mode, the maximum energy production reached $0.5 \mathrm{Wh} / \mathrm{mol} \mathrm{H}_{2}$.

\section{Keywords}

Chlor-alkali; reversible electrochemical cells; ruthenium; microbubbles; electro-absorber

*author to whom all correspondence should be addressed: justo.lobato@uclm.es 


\section{Introduction}

In the search of a better management of green energies, the development of new energy storage devices is one of the most important challenges. Use of hydrogen was considered as a very promising option for a very long time (Grimes et al., 2008), although storage procedure is still a big handicap and, perhaps, the main reason of not having a wide applicability of the technology nowadays. Electrolysers based on the production of hydrogen and oxygen are at a really very high state of maturity with Technology Readiness Levels (TRLs) within the range 8-9 (Verhage et al., 2013). However, there is still gap for improvements, although in fields with a much lower TRLs, e.g for processes that implies the use of thermo-electrochemical cycles (Diaz-Abad et al., 2019) or the chloralkaline cycles (Bechtel et al., 2018; Cho et al., 2016). Proton Exchange Membrane Fuel Cell (PEMFC) technology is also at very high TRLs, both in low and high temperature PEMFCs. Reduction in the dependence of platinum as electrocatalyst is the key aspect yet to be improved. This can be obtained by working at high temperatures, in which kinetics are improved and the catalyst is less sensitive to poisoning. However, in those conditions, long term durability is still the big challenge to be overcome in the future years (Lobato et al., 2016).

Regarding new technologies with still low TRLs for the storage of energy as hydrogen, the chloralkaline cycle can be considered of interest, because of its promising features. This technology is based on the production and use of chlorine instead of oxygen as in conventional PEM technology. Electrolysis of brines is an extremely well-known process, in which the very important chloralkaline industry is based. Use of Mixed Metal Oxide (MMO) electrodes, with ruthenium oxides in the formulation, was a turning point in this process because of their extremely high efficiency and stability. As well, substitution of the mercury by the safer PEM membrane process was also a huge breakthrough point for this industry. Currently, very few researches can be done in this topic, which is at a very 
high TRL and, hence, there is only slot for small modifications in which economic interest is higher than the generation of scientific knowledge.

Chloralkaline electrolytic technology leads to the formation of hydrogen, sodium hydroxide and chlorine. As known, chlorine is a much powerful oxidant than oxygen, and this can be an advantage for the operation of fuel cells, reducing the dependence of platinum. However, this higher reactivity can seriously affect the stability of the different elements of the cell (in particular, the membranes) and long-term stability is becoming a key issue. Hence, the development of robust technological developments for these chloralkaline fuel cells is also an interesting point worthy of research (Thomassen et al., 2003; Thomassen et al., 2006a; Thomassen et al., 2006b; Thomassen et al., 2006c; Thomassen et al., 2010).

The chloralkaline cycle can be developed in gas or liquid phase. In the first case, the electrolyte is mandatorily the proton exchange membrane which is connected to the electrodes in a membrane-electrode assembly. Meanwhile, in the second case, the liquids can be selected in the anodic and cathodic compartments, acting simultaneously as electrolytes and absorbent of both gases (chlorine and hydrogen). In this work, we are interested in evaluating the performance of the chloralkaline process in liquid phase, using a reversible electro-absorption cell. Figure 1 shows a summary of key processes which are expected to occur during this energy storage cycle.

The fuel cell and the electrolyzer operation modes can be carried out in the same electrochemical cell and with the same electrodes. Thus, a reversible electrochemical cell can be operated as electrolyzer or fuel cell depending on the reagents that are fed into the electrodic compartments. It allows the use of a single equipment for the storage of energy as chemicals. Thus, in this case, the connection of this reversible cell with green energy can allow the formation of hydrogen and chlorine, which can be stored. Then, when the 
demand of electricity is higher than that provided by renewable energies, these reagents are fed to the electrodic compartments and electricity is produced. The reactive absorption of chlorine, which is disproportionated into hypochlorous acid and chloride, is expected to provide a very high solubility of this oxidant. Hence, this absorption step is not expected to be a limiting step. Conversely, solubility of hydrogen in aqueous electrolytes is very low and, because of that, absorption of hydrogen into a liquid electrolyte may become a limiting issue. For this reason, absorption stage in the anodic compartment is a very important point and a high surface area between hydrogen gas and the electrolyte can be of interest to yield a successful process. On the other hand, in a reversible cell, the electrodes used in both operation modes are the same, so they must show good performance when acting as anodes or cathodes, because they are going to perform in both roles. For hydrogen oxidation, platinum is known to be a very good electrode. For chlorides oxidation, $\mathrm{MMO}$ based on $\mathrm{RuO}_{2}$ are the most widely used electrodes (Tran Le et al., 2015). It is interesting to assess the performance of both types of electrodes when they are used in the reduction of chlorine and protons to produce hydrogen.

Considering this background, this work is focused on the evaluation of a reversible PEM electrochemical cell, equipped with the same membrane and electrodes and operating at room temperature. It is not aimed to optimize performance but to check the concept and determine the main shortcomings in order to develop electro-absorber technologies for the storage of energy using the chloralkaline process. Because of its expected high influence, it is also aimed to evaluate the influence of the composition of the electrode in which the oxidation/reduction of chlorine species is going to take place. To do this, the $\mathrm{Ru} / \mathrm{Pt}$ ratio in the electrode in charge of the electrochemistry of chlorine has been changed from 1 to 9. For this, electrodes with close $\mathrm{Ru} / \mathrm{Pt}$ ratios (1,2 and 4) are used so that the results obtained are comparable between them. In turn, to check that the amount of $\mathrm{Ru} / \mathrm{Pt}$ 
really influenced the performance of the electrochemical cell, a higher $\mathrm{Ru} / \mathrm{Pt}$ ratio is used (9).

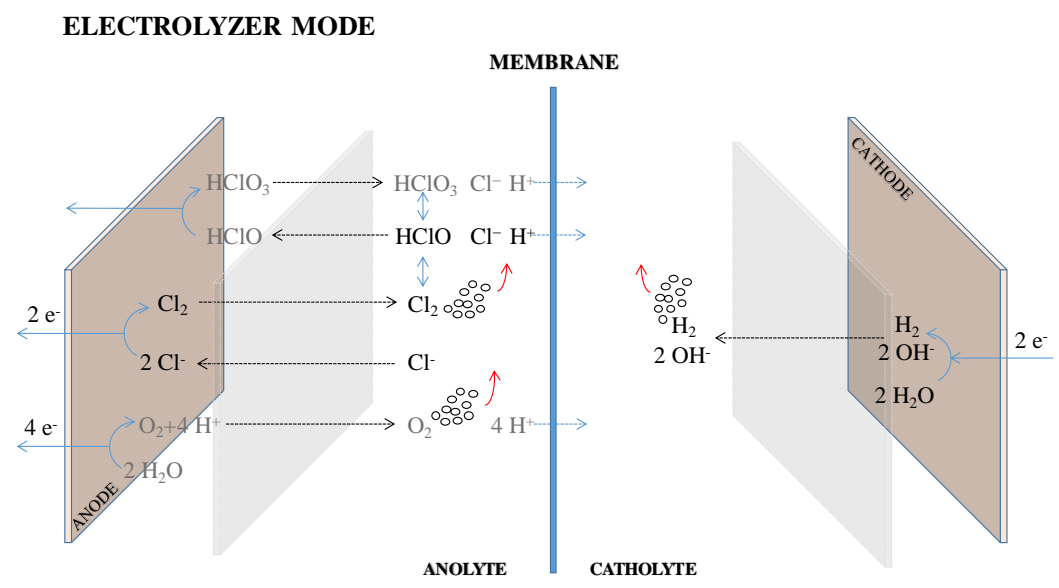

FUEL CELL MODE

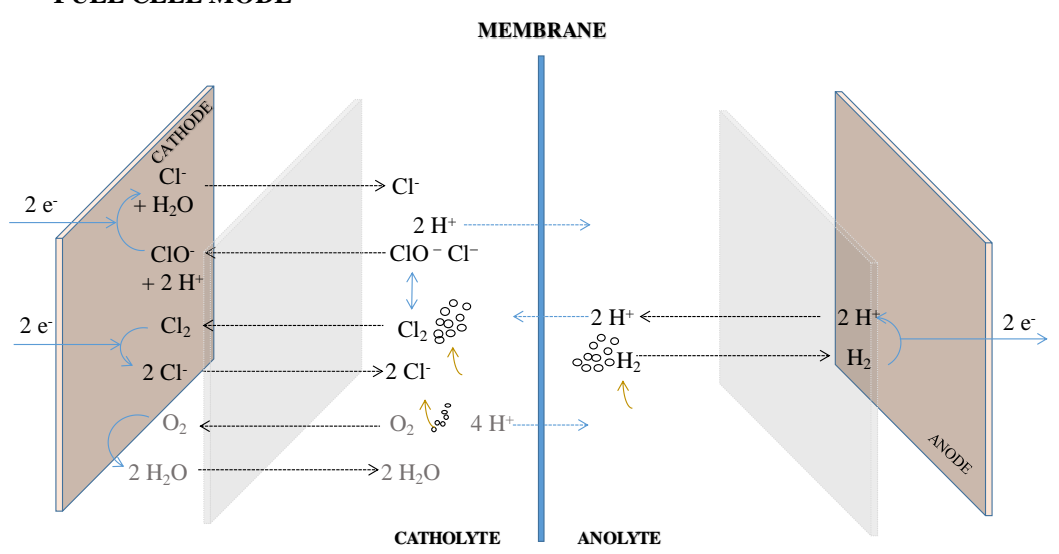

Figure 1. Expected reactions in the reversible hydrogen/chlorine electro-absorber cells

\section{Materials and Methods}

Electrodes synthesis. The electrodes consist of mixed metal oxides (MMO) coatings prepared on titanium plates $(2.0 \times 1.0 \times 0.1 \mathrm{~cm})$ used as electrode support. Plates were chemically pre-treated, first in hot hydrochloric acid $20 \%(\mathrm{w} / \mathrm{w})$ for 15 minutes and, then, in hot oxalic acid 10\% (w/w) for other 15 minutes. Finally, the supports were washed with Milli-Q water (resistivity $\geq 18.2 \mathrm{M} \Omega \mathrm{cm}$ at $25^{\circ} \mathrm{C}$ ). For the preparation of the electrodes, the Pechini Method was followed (Freitas et al., 2006a; Freitas et al., 2006b). The metallic precursors are dissolved at $60^{\circ} \mathrm{C}$ in an ethylene glycol (Merck, 99.0\% v/v) solution in citric acid (Sigma, 99.5\% w/w), with EG/CA/metallic precursors molar ratio 
of 10:3:1. For the electrodes in charge of the electrochemistry of chlorine in both fuel cell and electrolyzer operation modes, different $\mathrm{Ru} / \mathrm{Pt}$ contents were used to prepare the $\mathrm{Ti} / \mathrm{Ru}_{(\mathrm{x})} \operatorname{Ti}_{(1-\mathrm{x}-\mathrm{y})} \mathrm{Pt}_{(\mathrm{y})}$ electrodes i.e., $\mathrm{x}=0.2,0.3,0.4$ and $0.45 ; \mathrm{y}=0.2,0.1,0.1$ and 0.05 . Thus, the $\mathrm{RuCl}_{3} \cdot 3 \mathrm{H}_{2} \mathrm{O}$ (Alfa Aesar, $\mathrm{Ru} 38 \%$ w/w), $\mathrm{C}_{16} \mathrm{H}_{36} \mathrm{O}_{4} \mathrm{Ti}$ (Sigma-Aldrich, 97\% v/v) and $\mathrm{H}_{2} \mathrm{PtCl}_{6} \cdot 7 \mathrm{H}_{2} \mathrm{O}$ (Merck, $\mathrm{Pt} 40 \%$ w/w) were used as precursors of the $\mathrm{RuO}_{2}, \mathrm{Pt}$ and $\mathrm{TiO}_{2}$, respectively. For the electrode in charge of the hydrogen electrochemistry in both electrolyzer and fuel cell operation modes, no ruthenium salts were used and only one formulation was made: $\mathrm{Ti} / \mathrm{Ti}_{0.8} \mathrm{Pt}_{0.2}$.

The precursor solutions were airbrushed onto the $\mathrm{Ti}$ support. The procedure was as follows: the material was thermally treated at $130^{\circ} \mathrm{C}$ for 30 min to eliminate water, $250^{\circ} \mathrm{C}$ for $10 \mathrm{~min}$ and then at $400^{\circ} \mathrm{C}$ for $5 \mathrm{~min}$ to eliminate the organic materials, which led to the formation of the metallic film. This procedure was repeated five times and, at the end, the Pt loading for each electrode produced was $0.65 \mathrm{mg} \mathrm{cm}^{-2}$. Finally, the electrodes were cooled until room temperature.

Chemical analysis. Chlorine species $\left(\mathrm{Cl}^{-}, \mathrm{ClO}^{-}, \mathrm{ClO}_{3}^{-}, \mathrm{ClO}_{4}^{-}\right)$were measured by ion chromatography using Shimadzu LC-20A equipment column, Shodex IC I-524A; mobile phase, $2.5 \mathrm{mM}$ phthalic acid at $\mathrm{pH}$ 4; flow rate, $0.5 \mathrm{~mL} \mathrm{~min}^{-1}$. In the case of hypochlorite, its peak interferes with the chloride ion; for this reason, the determination was carried out by spectrophotometry. The procedure was as follows: $3 \mathrm{~mL}$ of the sample were mixed with $50 \mu \mathrm{L}$ of sodium chloride $(3 \mathrm{M})$. The absorbance of the solution was measured a wavelength of $293 \mathrm{~nm}$ by means of an Agilent 300 Cary series UV-Vis spectrophotometer. The $\mathrm{pH}$ was measured with a GLP22 Crison $\mathrm{pH}$ meter.

Electrochemical analysis. The electrochemical characterization was performed with a AUTOLAB/PGSTAT 302N potentiostat/galvanostat. All experiments were conducted at atmospheric pressure and room temperature. The cyclic voltammetries were measured in 
the potential range -1.7 to $1.7 \mathrm{~V}$ using a sweep rate of $50 \mathrm{mV} \mathrm{s}^{-1}$, the polarization curve in the potential range 0 to $1.4 \mathrm{~V}$ and. Potentiometric $(7.4 \mathrm{~V}$ in electrolysis mode, $0.5 \mathrm{~V}$ in fuel cell mode) and chronoamperometric $\left(100 \mathrm{~mA} \mathrm{~cm}^{-2}\right)$ tests were carried out for each electrode to evaluate their performance.

Experimental set-up. The used cell in this work consists of two chambers $\left(4 \mathrm{~cm}^{3}\right.$ volume each one) separated by a commercial Proton Exchange Membrane (Nafion-117). It is an in-house electro-absorption cell that can be used as a reversible electrochemical cell operating in electrolyzer and fuel cell mode. The electrochemical PEM cell is formed by two silicon plates, which are attached to the membrane, to avoid liquid losses. MMO electrodes were used in both chambers $\left(2 \mathrm{~cm}^{2}\right.$ each), manufactured as stated before. A layout of the experimental setup with the configurations electrolyzer/fuel cell is shown in Figure 2. For the electrolytic operation mode (Part a), both compartments, anodic and cathodic, were fed with a concentrated dissolution of sodium chloride (2.0 M). Sodium chloride (99.5\% w/w) used to prepare the solutions was purchased from PanReac (Spain). These electrolytes were continuously recirculated by means of two peristaltic pumps. Besides, the feed tanks were connected to a gas collection system, whose flow rate was measured by means of a communicating vessel system. The electrochemical cell was connected to a potentiostat/galvanostat AUTOLAB PGSTAT 302N and it was working at two different operation conditions: potentiostatic (constant voltage of $7.4 \mathrm{~V}$ ) and galvanostatic mode (constant current density of $100 \mathrm{~mA} \mathrm{~cm}^{-2}$ ). 


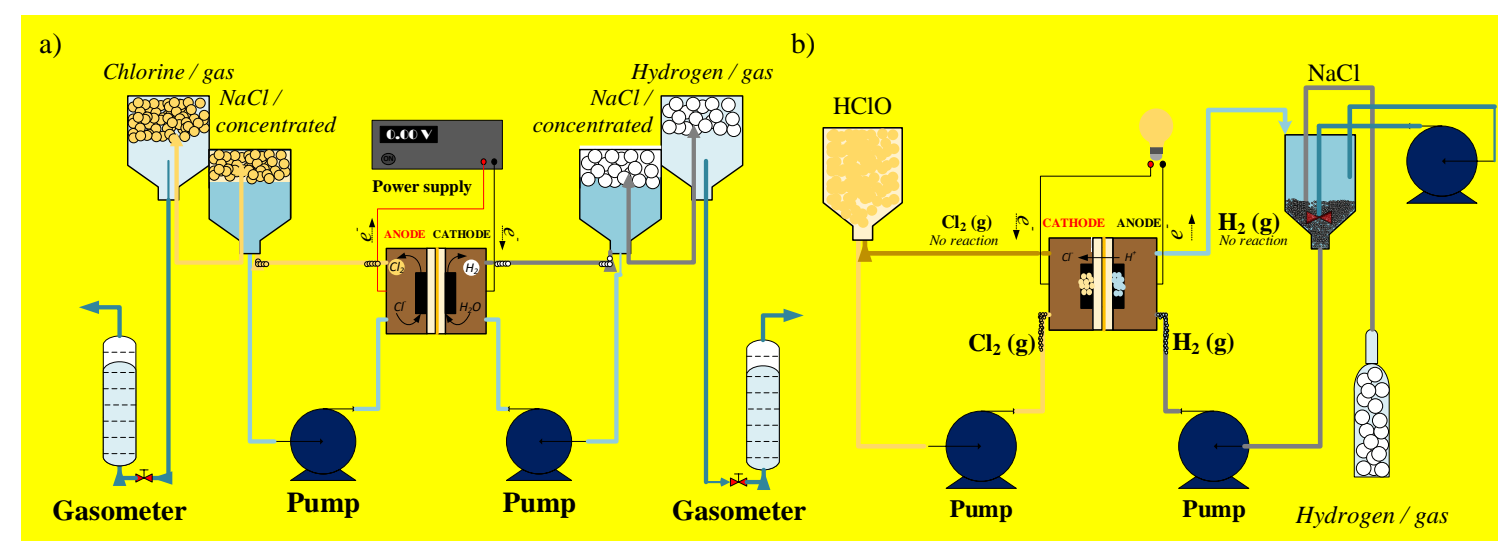

Figure 2. Layout of the experimental set-up used a) electrolysis mode b) fuel cell mode In fuel cell mode (part b), in the chlorine-side, a solution of hypochlorous acid (1M $\mathrm{HCl}$ / $1 \mathrm{M} \mathrm{HClO})$ was fed into the cell. $\mathrm{HCl}(37 \% \mathrm{v} / \mathrm{v})$ was purchased from PanReac (Spain) and $\mathrm{HClO}(10 \% \mathrm{v} / \mathrm{v})$ from Sigma-Aldrich (Spain). On the hydrogen-side, a two-phase flow was introduced into the cell. This consisted of a liquid phase of dilute sodium chloride $(1.0 \mathrm{M})$ saturated with microbubbles of $\mathrm{H}_{2}$ (gas) supplied from an external source (200 bar tank, 99,999\%), which allows continuous transport of liquid into the cell and to the membrane surface, therefore keeping it hydrated. During cell operation, both electrolytes were recirculated through the cathodic and anodic, respectively, compartments. The cell was working at a constant voltage of $0.5 \mathrm{~V}$ for $100 \mathrm{~min}$ (potentiostatic mode).

\section{Results and discussion}

Figure 3 shows results obtained in the electrolysis of $\mathrm{NaCl}$ at two different operation conditions, labeled in this work as soft (exerted current density of $100 \mathrm{~mA} \mathrm{~cm}{ }^{-2}$, approximate cell voltage of $3.5 \mathrm{~V}$ ) and harsh (exerted cell potential of $7.4 \mathrm{~V}$, approximate current density of $475 \mathrm{~mA} \mathrm{~cm}{ }^{-2}$ ). 

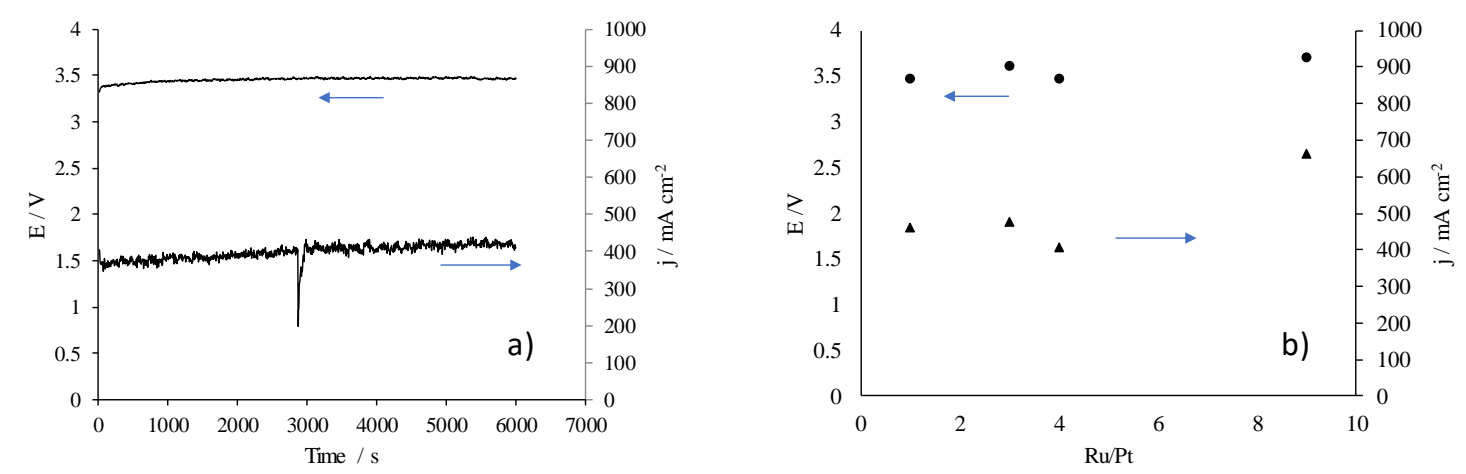

Figure 3. Current and voltage behavior of the cells during the electrolysis tests. a) Time course of the cell voltage (for a galvanostatic operation at $100 \mathrm{~mA} \mathrm{~cm}{ }^{-2}$ ) and current density (for a potentiostatic operation at cell voltage of $7.4 \mathrm{~V}$ ) during the electrolysis tests carried out with the $\mathrm{Ti} / \mathrm{Ru}_{0.4} \mathrm{Ti}_{0.5} \mathrm{Pt}_{0.1}$ anode b) Steady state current densities $(\mathbf{\Delta})$ for a cell voltage of $7.4 \mathrm{~V}$ and steady-state cell voltages $(\bullet)$ attained for a current density of $100 \mathrm{~mA} \mathrm{~cm}^{-2}$ during the different electrolysis carried out with different anode materials. Cathode: $\mathrm{Ti} / \mathrm{Ti}_{0.8} \mathrm{Pt}_{0.2}$. Electrolyte: $\mathrm{NaCl} 2.0 \mathrm{M}$

As seen, regardless of the application of potentiostatic or galvanostatic conditions, the current and the cell voltage remained almost constant during the complete electrolysis tests (in fact, just a small improvement is observed), indicating that no significant changes in the ohmic resistance of the cell are taking place and, hence, that no deterioration of the electrodes or membrane is occurring. This observation is repeated for the other tests carried out with the cells equipped with the electrodes with different Ru/Pt coatings. Likewise, it can be observed that the influence of the ratio $\mathrm{Ru} / \mathrm{Pt}$ contained in the anode on the electrical characteristics of the cell is very low. Only for the highest ratio used, a small increase in the current density is observed when operating at harsh conditions, suggesting a lower resistance of this composition.

In Figure 4, for the same tests shown in Figure 3-a, the formation of products of the electrolysis is plotted, as well as the $\mathrm{pH}$ changes observed during the tests. In the cathode, 
the only expected reaction is the reduction of water to hydrogen, which accounts in the anode for the oxidation of chloride into chlorine (later transformed into hypochlorous acid or even in hypochlorite depending on the $\mathrm{pH}$ by disproportionation) and for the oxidation of water to oxygen. The first is the desired reaction in this regenerative cell, while the second is a side reaction which is aimed to be minimized. As seen, both chlorine and oxygen are formed during the electrolysis, being chlorine the primary product at both conditions tested. These products have been observed in other works for similar system and using iridium coated titanium based electrodes(Shim et al., 2015). Mass balance between the cathodically formed hydrogen and the anodically formed oxygen and chlorine is verified.

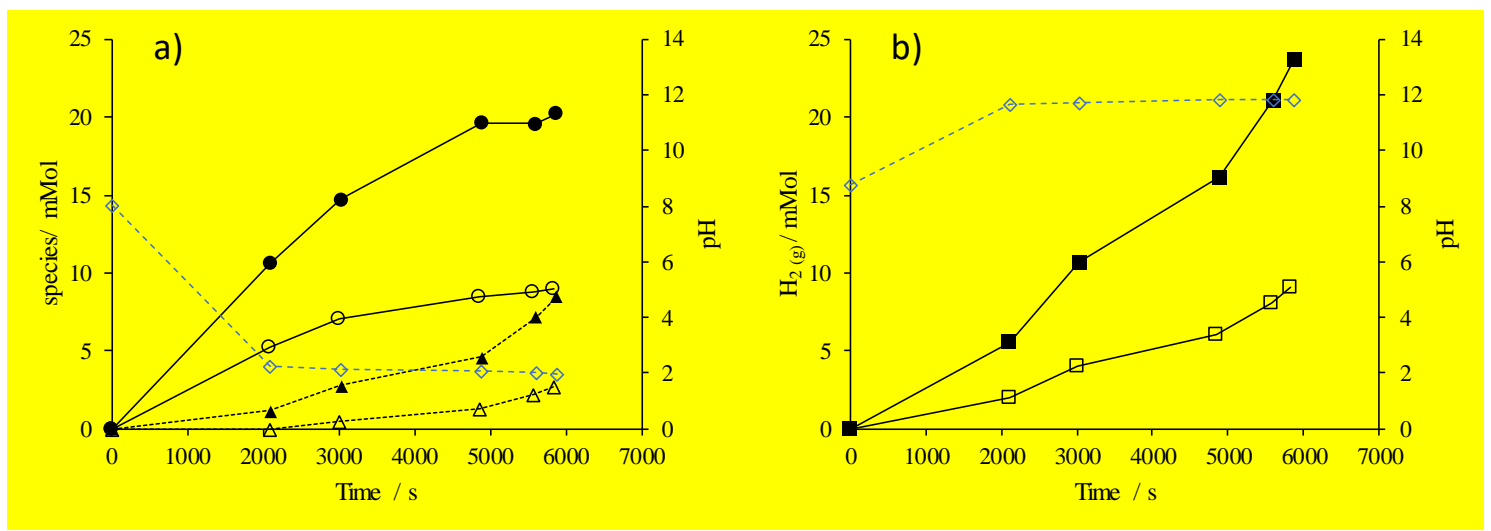

Figure 4. Speciation produced during the electrolysis tests carried out using $\mathrm{Ti} / \mathrm{Ru}_{0.4} \mathrm{Ti}_{0.5}$ $\mathrm{Pt}_{0.1}$ anode. $\bullet$ chlorine $\boldsymbol{\Delta}$ oxygen $\boldsymbol{\square}$ hdrogen $\diamond \mathrm{pH}$. Full points: electrolysis at $7.4 \mathrm{~V}$. Empty points: electrolysis at $100 \mathrm{~mA} \mathrm{~cm}{ }^{-2}$. Cathode: $\mathrm{Ti} / \mathrm{Ti}_{0.8} \mathrm{Pt}_{0.2}$; electrolyte: solution containing $2.0 \mathrm{M} \mathrm{NaCl}$

Composition of the formulation of the coating used in the anode is expected to have a significant influence on the performance of the electrolytic cell (Tran Le et al., 2015), and, because of that, this input was studied in this work using $\mathrm{Ru} / \mathrm{Pt}$ ratios within the range 1.0 to 9.0. Thus, this influence is observed in Figure 5, where it can be seen that at soft conditions a molar ratio $\mathrm{Ru} / \mathrm{Pt}$ between 3 and 9 assures the maximum production of 
chlorine attainable. This means that increasing the amount of $\mathrm{Ru}$ does not have an electrocatalytic effect in conditions in which water electrolysis is not favored. However, in the so-called harsh conditions, where the discharge of water is the primary reaction, the Pt contained seems to be more important and a maximum value is obtained for a ratio of 3, for which almost 5 times more chlorine than oxygen is formed. This means that anodes with very high ratios of $\mathrm{Ru}$ are promoting the formation of oxygen from the hydroxyl radicals formed in the oxidation of water, more than the oxidation of chlorides to chlorine. MMO electrodes are known to combine with hydroxyl radicals formed during the discharge of water, leading to an unstable higher oxidation-state ruthenium oxide, which is the real responsible for the mediated formation of chlorine together with the direct exchange of electrons between the chlorides and the surface of the electrodes. This mechanism is exhaustively studied and it has also been described for other metal oxides (Foti et al., 1999). Large concentrations of Ru favor the discharge of water from this higher oxidation state, which intermediate values seem to have a positive effect. This better performance of the anode made with an intermediate $\mathrm{Ru} / \mathrm{Pt}$ ratio is also observed in terms of the efficiency of the electrolytic process, in which it is observed that a $\mathrm{Ru} / \mathrm{Pt}$ ratio of 3-4 allows the more efficient formation of products, as compared to higher and lower values, being higher the efficiencies observed operating at low current densities, which can be explained in terms of the lower effect of mass transfer limitations. Thus, in an efficiency value of $8.0 \mathrm{mmol} / \mathrm{Wh}$ was achieved for the electrode with a $\mathrm{Ru} / \mathrm{Pt}$ ratio of 4. 

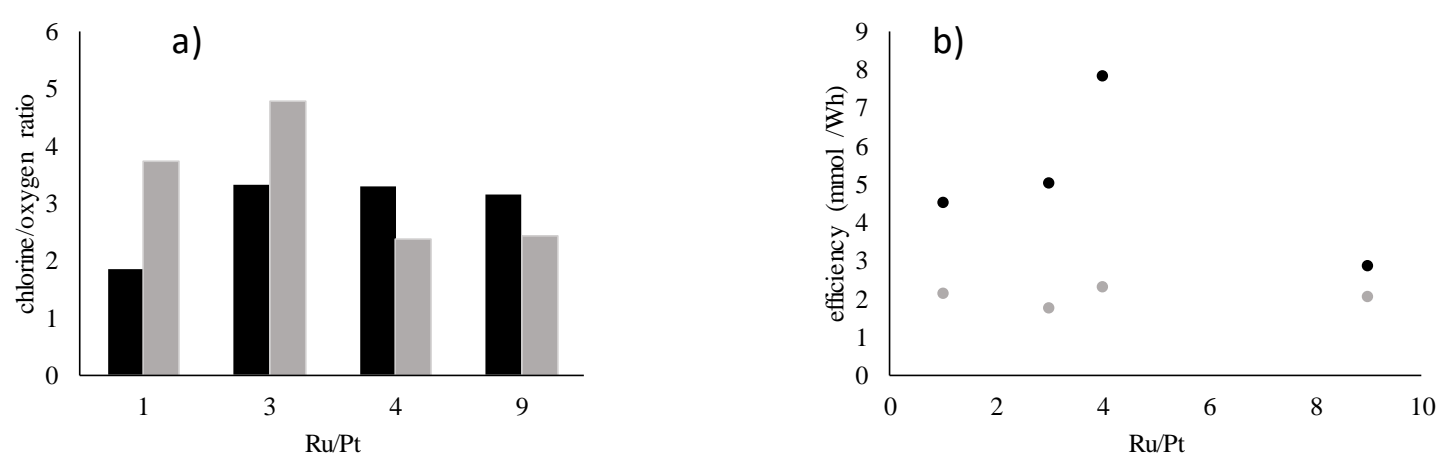

Figure 5. Influence of the ratio $\mathrm{Ru} / \mathrm{Pt}$ on the anodic formation of chlorine / oxygen a) and on the efficiency of the process b), during the electrolysis of $\mathrm{NaCl} 2.0 \mathrm{M}$. Black points: electrolysis at $100 \mathrm{~mA} \mathrm{~cm}{ }^{-2}$; grey points: electrolysis at $7.4 \mathrm{~V}$. Ti/ $\mathrm{Ti}_{0.8} \mathrm{Pt}_{0.2}$.

These observations can also be explained by evaluating the voltammetric behavior of the system. Thus, in Figure 6a, the voltammograms carried out operating in electrolytic mode are shown, where the behavior observed in the positive range of potentials is very relevant. As observed, the electrochemical response in the range $1.0-1.5 \mathrm{~V}$ of the electrodes, where the direct oxidation of chlorides occurs, seems to be more important as the ratio $\mathrm{Ru} / \mathrm{Pt}$ increases. In the anodic reaction, not only the oxidation of the chloride to hypochlorous acid takes place, but also the formation of oxygen occurs. This potential interval (1.0-1.5V) indicates that the evolution of oxygen is observed at less positive potentials and the evolution of chlorine is seen at the most positive potentials. (Macounova et al., 2019). Thus, the electrode with the $\mathrm{Ru} / \mathrm{Pt}$ ratio of 1 has almost no response in this range (in agreement with the higher production of oxygen observed in the bulk electrolysis) while in the case of the electrode with a $\mathrm{Ru} / \mathrm{Pt}$ ratio of 9 , the better voltammetric performance of this electrode is not caused by the direct oxidation but by the overlapping effect of a faster water discharge. Electrodes with an intermediate $\mathrm{Ru} / \mathrm{Pt}$ ratio (3-4) show a lower effect of this oxygen water discharge, which is consistent with the bulk response obtained. In part $b$, the voltammetric response of the regenerative cell 
operated in fuel cell mode (feeding hydrogen and hypochlorous acid) is shown. In this case, the most important range of observation is in between 0 and $1.5 \mathrm{~V}$ (vs SHE) where a peak related to the reduction of the hypochlorous acid is clearly observed. This range of potentials between 0 and $1.5 \mathrm{~V}$ is restricted by the chloride evolution at less positive potentials (Kodera et al., 2005). For this peak, the electrode with the Ru/Pt of 4 seems to have the best response and the others show a very similar behavior. Cathodic zone indicates the very complex reactivity observed in electrolytic mode when feeding these reagents to the electrochemical cell.

Therefore, it can be concluded that, after the evaluation of these voltammograms, the anodic and cathodic processes that take place in the regenerative cell when it works in electrolysis mode and in fuel cell mode are influenced by the composition of the electrode in charge of the chlorine electrochemistry. Furthermore, it is observed that the behavior of the electrochemical cell in both modes of operation is similar, obtaining a better working response to the electrode with the $\mathrm{Ru} / \mathrm{Pt}$ ratio of 4 .

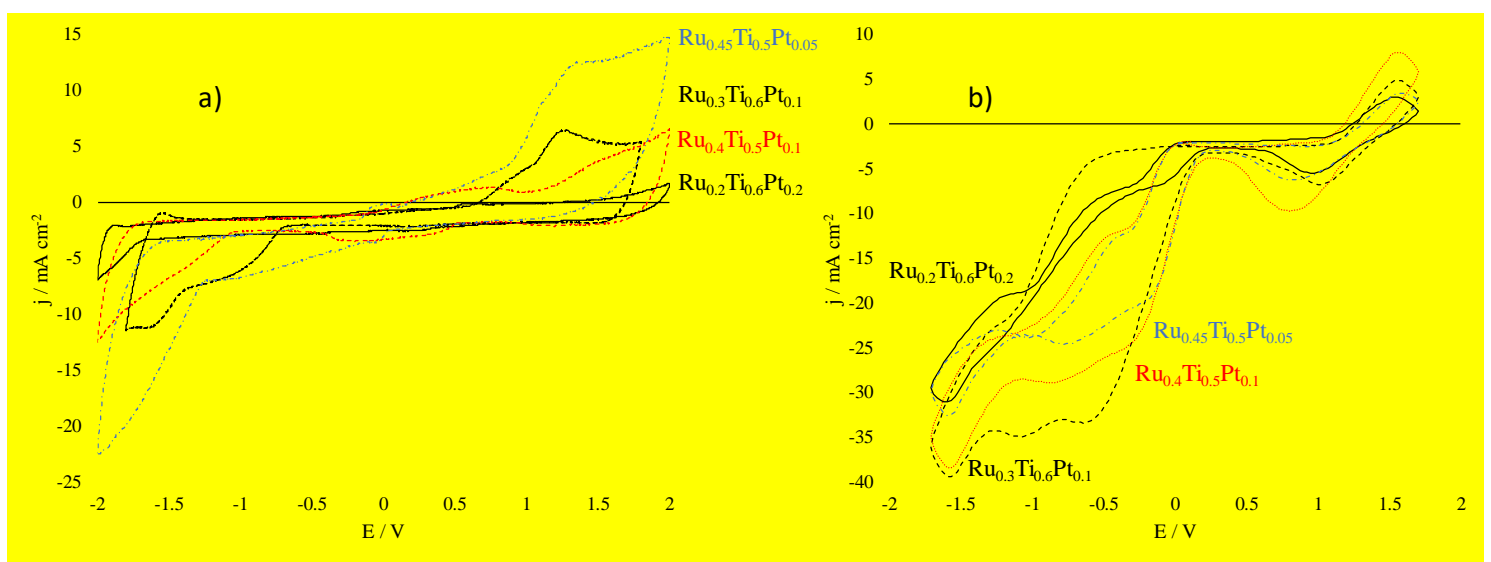

Figure 6. Voltammetric behavior operating in electrolyzer (Part a) and fuel cell (Part b) modes. Electrolyzer operation: cell fed with $2.0 \mathrm{M} \mathrm{NaCl}$ solution in both compartments. Fuel cell operation: cell fed with hypochlorous acid and hydrogen microbubbles in water. Counter electrode: $\mathrm{Ti} / \mathrm{Ti}_{0.8} \mathrm{Pt}_{0.2}$.

$-\mathrm{Ru}_{0.2} \mathrm{Ti}_{0.6} \mathrm{Pt}_{0.2} ;-\cdots-\mathrm{Ru}_{0.3} \mathrm{Ti}_{0.6} \mathrm{Pt}_{0.1} ; \cdots \cdots \cdots \cdots \mathrm{Ru}_{0.4} \mathrm{Ti}_{0.5} \mathrm{Pt}_{0.1} ;-\cdot-\cdot-\mathrm{Ru}_{0.45} \mathrm{Ti}_{0.5} \mathrm{Pt}_{0.05}$ 
Figure 7 shows the polarization curves obtained by the cell with electrode with the $\mathrm{Ru} / \mathrm{Pt}$ ratio of 4 , where the observed fluctuations (more important at higher current densities) are explained in terms of the feeding of hydrogen microbubbles because, in this work, what it is really tested is a gas-liquid electrochemical cell, in which in both electrodic compartments a liquid electrolyte is fed. In the case of the cathode, at $\mathrm{pH}$ of 2 , hypochlorous acid is the primary specie because of the high solubility of chlorine caused by its disproportionation. In the case of the anode, hydrogen is provided by means of a mechanism microbubble producing device. The higher fluctuations at higher currents can be easily explained because of the more exigent conditions, in which the gaseous reagent can be more easily exhausted at the conditions of the test. As seen, the OCV is $1.4 \mathrm{~V}$, which is a rather good value, which indicates that reduction of chlorine is the most important process (oxygen is not fed but hypochlorous acid) and the maximum current reached is not very high, although it has to be considered that the type of cell used is not optimized because in this work, it was only aimed a proof of concept of the complete technology.

Regarding changes in the current density produced during operation at a cell voltage of $0.5 \mathrm{~V}$, obtained results using the electrode with the ratio $\mathrm{Ru} / \mathrm{Pt}$ of 4 are shown in part $\mathrm{b}$. As seen, despite starting at a higher value, the produced current quickly stabilizes after $400 \mathrm{~s}$ in a value of $2.4 \mathrm{~mA} \mathrm{~cm}{ }^{-2}$, from which only disturbances modify it. The decrease is observed in the other tests carried out in this work and suggests that operation conditions undergone at the beginning of the test favors the current production. 

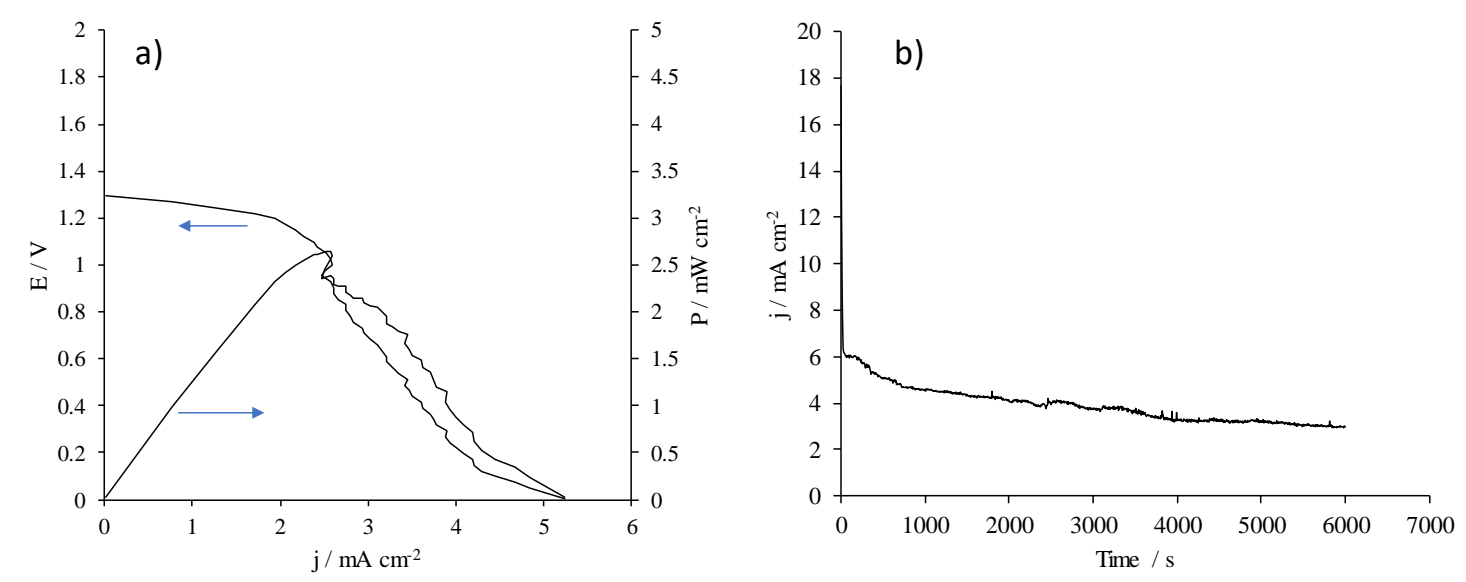

Figure 7. Polarization curves and time-course of the current density during the operation at $0.5 \mathrm{~V}$ of a fuel cell fed with $1.0 \mathrm{M} \mathrm{HClO}$ in the cathodic compartment and with water + hydrogen microbubbles in the anodic compartment. Anode: $\mathrm{Ti} / \mathrm{Ru}_{0.4} \mathrm{Ti}_{0.5} \mathrm{Pt}_{0.1}$. Cathode: $\mathrm{Ti} / \mathrm{Ti}_{0.8} \mathrm{Pt}_{0.2}$.

Figure 8 shows the changes in the amount of the different chemical species involved when the cell was operated in fuel cell mode. As seen, the $\mathrm{pH}$ decreases rapidly in both compartments and during the initial $400 \mathrm{~s}$ (in which the current was higher) the rate of hydrogen oxidized and hypochlorous acid reduction (which almost match) is much higher. Then, this production continues at a constant rate, indicating that the $\mathrm{pH}$ control may have a very important role for increasing the rate of the processes. Part a of the Figure 8 also shows the amount of chlorine species that cross the membrane and go from the cathodic to the anodic compartment. Although, it is not very relevant, it clearly suggests that the prevention of crossover by using improved membranes with lower crossovers is very important. In Part b, the effect of the cathode composition is observed. As in the case of the electrolyzer, an intermediate ratio $\mathrm{Ru} / \mathrm{Pt}$ seems to have a very positive effect on the reactivity of the chlorinated species and hence on the performance of the cell. As expected, there is no influence of the $\mathrm{Ru} / \mathrm{Pt}$ ratio on the crossover of chlorinated species from the cathode to the anode. 

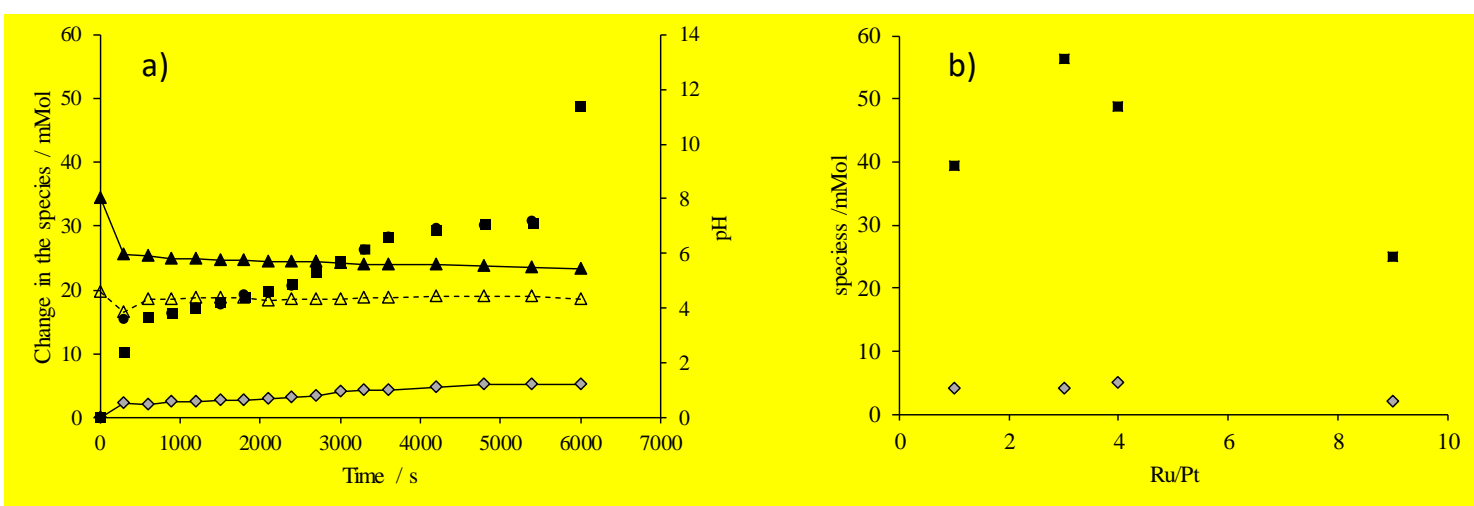

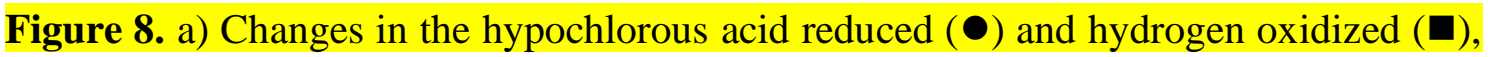
chlorinated species passing through the membrane $(\diamond)$ and $\mathrm{pH}$ in the anodic $(\boldsymbol{\Delta})$ and cathodic $(\triangle)$ compartments during the operation of a fuel cell at $0.5 \mathrm{~V}$ equipped with the a $\mathrm{Ti} / \mathrm{Ru}_{0.4} \mathrm{Ti}_{0.5} \mathrm{Pt}_{0.1}$ cathode. $\mathrm{B}$ ) effect of the $\mathrm{Ru} / \mathrm{Pt}$ ratio on the hydrogen production and chlorinated species crossover $(\diamond)$ at the steady state. Anode: $\mathrm{Ti} / \mathrm{Ti}_{0.8} \mathrm{Pt}_{0.2}$.

Figure 9 shows that the OCV value measured after the operation of the cell is almost not influenced by the ratio $\mathrm{Ru} / \mathrm{Pt}$, as expected. On the opposite, both the maximum current density and operating current density obtained at $0.5 \mathrm{~V}$ show a maximum for $\mathrm{Ru} / \mathrm{Pt}$ of 4 which agrees with the voltammetric response observed. However, differences observed (except for the coating with the lowest ratio of $\mathrm{Ru}$ ) are not very important and hence, it can be stated that for $\mathrm{Ru} / \mathrm{Pt}$ ratios over 3 the system performance in the operation as fuel cell is good enough. 


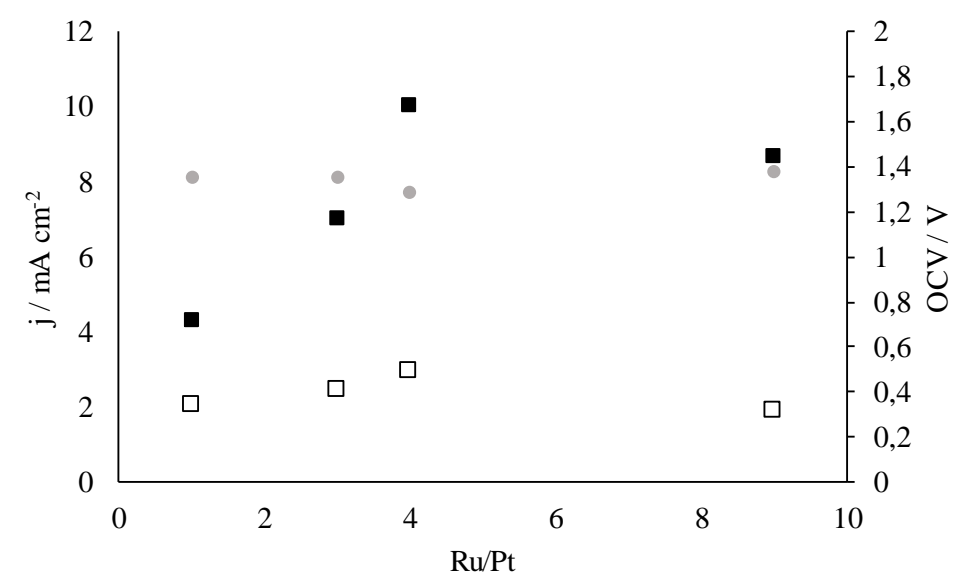

Figure 9. Influence of the cathodic Ru/Pt ratio on the maximum current density ( $\mathbf{\square})$, operation current density $(\square)$ at $0.5 \mathrm{~V}$ and $\mathrm{OCV}(\bullet)$ at the steady state. Anode: $\mathrm{Ti} / \mathrm{Ti}_{0.8} \mathrm{Pt}_{0.2}$.

The trends observed in the current densities are reflected in the obtained power densities (part a of Figure 10), with maximum power density of $3.0 \mathrm{~mW} \mathrm{~cm}{ }^{-2}$, which is interesting taking into account that the used cell has a liquid electrolyte $\left(\mathrm{H}_{2}\right.$ was not fed directly but in form of microbubbles) at room temperature in which the transport of hydrogen to the surface of the electrodes is rather limited and kinetic is not favored. However, the lower consumption of reagent makes more efficient the cell operated with the higher $\mathrm{Ru} / \mathrm{Pt}$ ratio as it is observed in Figure 10, where a value of $0.5 \mathrm{Wh} / \mathrm{mol} \mathrm{H}_{2}$ approx. is achieved. Nevertheless, this suggests (in combination with the results obtained during the operation in the electrolytic mode) that operating with electrodes with a ratio 3-4 can be interesting in reversible cells. 

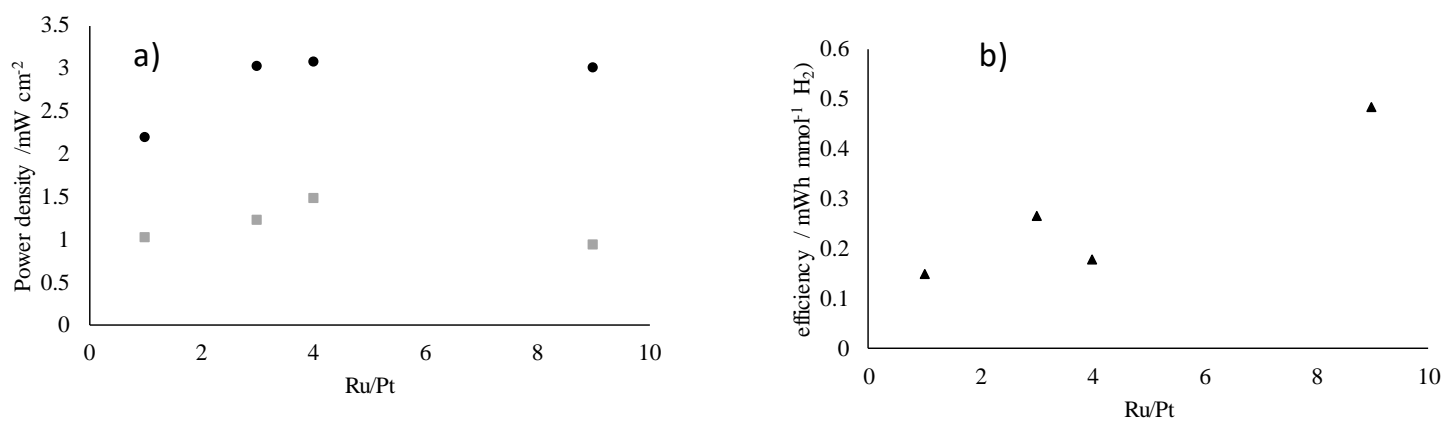

Figure 10. Influence of the cathodic $\mathrm{Ru} / \mathrm{Pt}$ ratio on the maximum power density $(\bullet)$ and operating power density $(\square)$ and on the efficiency $(\boldsymbol{\Delta})$ of fuel cells operating at $0.5 \mathrm{~V}$. Anode: $\mathrm{Ti} / \mathrm{Ti}_{0.8} \mathrm{Pt}_{0.2}$.

\section{Conclusions}

From this work, the following conclusions can be drawn:

- A reversible electrochemical cell for the chloralkaline process is feasible. This cell can oxidize a sodium chloride solution to produce chlorine (transformed by later disproportionation into hypochlorous acid and hypochlorite anions) and hydrogen. Feeding hypochlorous acid and hydrogen to the cell allows the production of electricity. Maximum production of hydrogen and chlorine is 8.0 mmol /Wh obtained operating at soft operating conditions. Maximum production of electricity efficiency reached is around $0.5 \mathrm{Wh} / \mathrm{mol}$ hydrogen.

- Ratio Ru/Pt in the electrode in charge of the electrochemistry of chlorine is very important. Values in the range 3-4 obtain satisfactory response in both electrolyser and fuel cell modes.

\section{Acknowledgements}

Financial support from the Spanish Ministry of Economy, Industry and Competitiveness and European Union through project CTQ2017-91190-EXP (AEI/FEDER, UE) is 
gratefully acknowledged. This work shows also first results of the Project PID2019-

107271RB-I00.

\section{Literature cited}

Bechtel S, Vidakovic-Koch T, Sundmacher K. Novel process for the exergetically efficient recycling of chlorine by gas phase electrolysis of hydrogen chloride. Chemical Engineering Journal 2018; 346: 535-548.

Cho KT, Tucker MC, Weber AZ. A Review of Hydrogen/Halogen Flow Cells. Energy Technology 2016; 4: 655-678.

Diaz-Abad S, Millan M, Rodrigo MA, Lobato J. Review of Anodic Catalysts for SO2 Depolarized Electrolysis for "Green Hydrogen" Production. Catalysts 2019; 9.

Foti G, Gandini D, Comninellis C, Perret A, Haenni W. Oxidation of organics by intermediates of water discharge on $\mathrm{IrO} 2$ and synthetic diamond anodes. Electrochemical and Solid State Letters 1999; 2: 228-230.

Freitas RG, Oliveira RTS, Santos MC, Bulhoes LOS, Pereira EC. Preparation of Pt thin film electrodes using the Pechini method. Materials Letters 2006a; 60: 1906-1910.

Freitas RG, Santos MC, Oliveira RTS, Bulhoes LOS, Pereira EC. Methanol and ethanol electroxidation using Pt electrodes prepared by the polymeric precursor method. Journal of Power Sources 2006b; 158: 164-168.

Grimes CA, Varghese OK, Ranjan S. Light, water, hydrogen: The solar generation of hydrogen by water photoelectrolysis, 2008.

Kodera F, Umeda M, Yamada A. Detection of hypochlorous acid. using reduction wave during anodic cyclic voltammetry. Japanese Journal of Applied Physics Part 2-Letters \& Express Letters 2005; 44: L718-L719.

Lobato J, Zamora H, Plaza J, Canizares P, Rodrigo MA. Enhancement of high temperature PEMFC stability using catalysts based on Pt supported on SiC based materials. Applied Catalysis B-Environmental 2016; 198: 516-524.

Macounova KM, Simic N, Ahlberg E, Krtil P. Hypochlorite Oxidation on RuO2-Based Electrodes: a Combined Electrochemical and In Situ Mass Spectroscopic Study. Electrocatalysis 2019; 10: 45-55.

Shim J-H, Jeong J-Y, Park J-Y. Effects of Operating Conditions on Improving Alkali and Electrical Efficiency in Chlor-Alkali Diaphragm Cell. International Journal of Electrochemical Science 2015; 10: 6338-6347.

Thomassen M, Borresen B, Hagen G, Tunold R. $\mathrm{H}-2 / \mathrm{Cl}-2$ fuel cell for co-generation of electricity and $\mathrm{HCl}$. Journal of Applied Electrochemistry 2003; 33: 9-13.

Thomassen M, Borresen B, Scott K, Tunold R. A computational simulation of a hydrogen/chlorine single fuel cell. Journal of Power Sources 2006a; 157: 271-283.

Thomassen M, Karlsen C, Borresen B, Tunold R. Kinetic investigation of the chlorine reduction reaction on electrochemically oxidised ruthenium. Electrochimica Acta 2006b; 51: 29092918.

Thomassen M, Sandnes E, Borresen B, Tunold R. Evaluation of concepts for hydrogen - chlorine fuel cells. Journal of Applied Electrochemistry 2006c; 36: 813-819.

Thomassen M, Sheridan E, Kvello J. Electrochemical hydrogen separation and compression using polybenzimidazole (PBI) fuel cell technology. Journal of Natural Gas Science and Engineering 2010; 2: 229-234. 
Tran Le L, Kim J, Yoon J. Physicochemical properties of RuO2 and IrO2 electrodes affecting chlorine evolutions. Journal of Industrial and Engineering Chemistry 2015; 21: 400-404.

Verhage AJL, Coolegem JF, Mulder MJJ, Yildirim MH, de Bruijn FA. 30,000 h operation of a $70 \mathrm{~kW}$ stationary PEM fuel cell system using hydrogen from a chlorine factory. International Journal of Hydrogen Energy 2013; 38: 4714-4724. 